\title{
Pelatihan Instalasi Listrik Bagi Pemuda Putus Sekolah dan Pengangguran
}

\author{
Perdana Putera $^{1 *}$, Edi Syafri ${ }^{2}$, Irwan $\mathrm{A}^{3}$, Trianto ${ }^{4}$, Indra Laksmana ${ }^{5}$. \\ ${ }^{1}$ Politeknik Pertanian Negeri Payakumbuh \\ E-mail: perdana@politanipyk.ac.id*
}

\begin{abstract}
ABSTRAK
Pelatihan instalasi listrik ini bertujuan untuk melatih kelompok masyarakat usia produktif untuk memiliki keterampilan dibidang instalasi listrik. Kegiatan ini diselenggarakan di labor instrumentasi dan kelistrikan Politeknik Pertanian Negeri Payakumbuh yang bekerjasama dengan Nagari Gurun. Pelatihan ini dilaksanakan dengan metode pemahaman teori dibidang instalasi listrik satu fasa dan tiga fasa sedangkan untuk praktek, peserta melakukan instalasi listrik satu fasa yang biasa dipakai untuk kelistrikan rumah tangga. Dari hasil evaluasi setelah pelatihan peserta dianggap memahami prinsip instalasi listrik, menghitung kebutuhan daya listrik serta mampu melakukan instalasi listrik satu fasa untuk rumah tangga. Namun demikian peserta masih perlu dibawah supervisi pekerja instalasi yang berpengalaman untuk bekerja secara profesional.
\end{abstract}

Kata kunci: Pelatihan; Usia Produktif; Instalasi Listrik satu fasa

\begin{abstract}
The objective of this electrical installation training is to train productive age community groups to have skills in the field of electrical installations. This activity was held in the labour instrumentation and electricity of Politeknik Pertanian Negeri Payakumbuh in collaboration with Nagari Gurun. This training was carried out with a theoretical understanding method of one-phase and three-phase electrical installations. At the same time, for practice, participants conducted a one-phase electrical installation that is commonly used for household electricity. From the evaluation after the training, the participants were considered to understand the principles of electrical installation, calculate electricity needs and be able to carry out single-phase electrical installations for households. However, participants still need to be supervised by experienced installation workers to work professionally.
\end{abstract}

Keywords: Training, productive age community; one-phase electrical installation

\section{PENDAHULUAN}

Bonus demografi atau tingginya jumlah usia produktif dalam suatu komunitas merupakan perangkat yang seharusnya dapat menjadi pendorong kemajuan masyarakat. Ketidakmampuan untuk memanfaatkan usia produktif dalam pengembangan masyarakat bisa jadi bumerang yang akan menjadi beban pemerintah maupun masyarakat (Sukmaningrum, 2017). 
Tanggung jawab untuk peningkatan keterampilan usia produktif ini tentu saja bukan hanya tanggung jawab pemerintah dan masyarakat namun juga institusi pendidikan sehingga menjadi salah satu dari tridharma perguruan tinggi. Di Kabupaten 50 Kota sendiri, usia produktif (lebih dari 15 tahun) yang menjadi pengangguran terbuka dari hasil sensus adalah sebanyak 7098 orang dengan rician sebanyak 4591 laki-laki dan 2507 perempuan (Statistik, 2017).

Politeknik Pertanian Negeri Payakumbuh merupakan satu-satunya institusi politeknik negeri yang berada di kabupaten 50 Kota. Dengan jumlah staf pengajar saat ini 175 orang yang memiliki berbagai latar belakang keilmuan dan pendidikan. Salah satu kewajiban staf pengajar yaitu mentransformasikan, mengembangkan dan menyebarluaskan ilmu pengetahuan dan teknologi kepada masyarakat melalui kegiatan pendidikan, penelitian dan pengabdianst (Kemenristek, 2017). Bentuk pengabdian tersebut diberikan dengan memberikan penyuluhan dan pelatihan kepada kelompok masyarakat target dengan harapan akan meningkatkan kualitas dan daya saing masyarakat. Pelatihan ini bertujuan memberikan keterampilan bagi pemuda untuk melakukan pekerjaan instalasi listrik untuk rumah tangga mulai dari MCB hingga instalasi daya serta instalasi penerangan. Peserta pelatihan ini berasal dari Nagari Gurun Kabupaten 50 Kota.

\section{METODE}

\section{Persiapan}

Untuk sesi persiapan dilakukan dengan cara berkoordinasi dengan Wali nagari, untuk menseleksi peserta pelatihan. Untuk efektifnya pelatihan, permintaan peserta hanya untuk satu kelas pelatihan yaitu 5 orang dengan kriteria umur yaitu 16 hingga 35 tahun dan prioritas bagi pemuda yang sudah tidak lagi duduk dibangku sekolah atau tidak memiliki pekerjaan. Selanjutnya nama peserta yang sudah diseleksi dikirimkan secara tertulis ke institusi politeknik. Peserta yang sudah diseleksi kemudian dihubungi untuk mendeskripsikan kegiatan serta penentuan waktu dan tempat pelaksanaan pelatihan. 


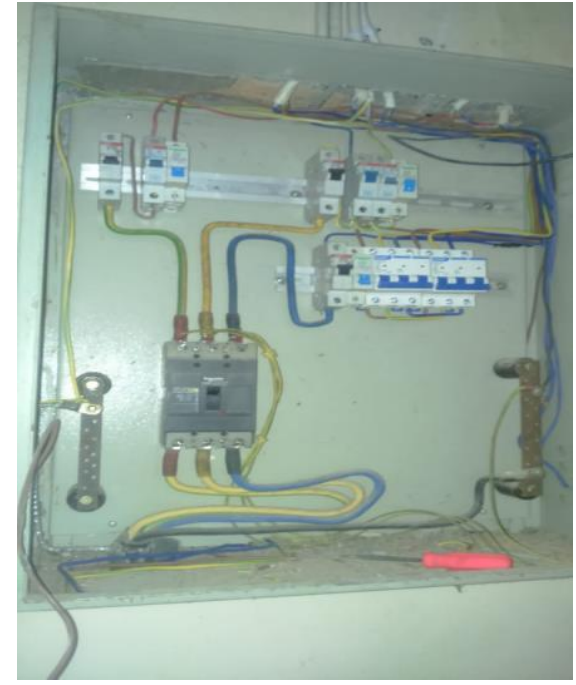

(a)

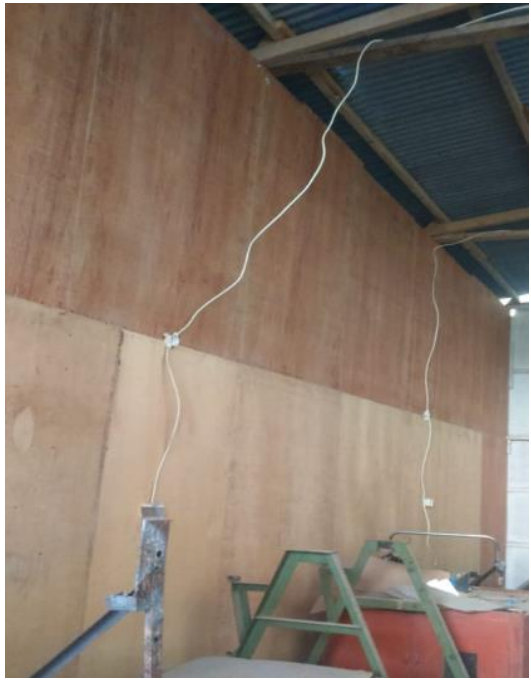

(b)

Gambar 1. Persiapan dan pengkondisian pelatihan (a) kotak hubung bagi (b) pemasangan kabel

Persiapan tempat dilakukan dengan pengkondisian tempat pelatihan yang dianggap paling mendekati proses instalasi listrik di lapangan. Pelatihan ini dilakukan di Labor instrumentasi dan kelistrikan Politeknik Pertanian Negeri Payakumbuh. Pengkondisian yang dimaksud adalah dengan membuat instalasi yang berada diluar dinding sehingga jalur instalasi bisa dilihat secara langsung oleh para peserta.

\section{Pelaksanaan}

Pelatihan ini dibagi dalam dua sesi yaitu sesi teori dan sesi praktek. Sesi teori menjelaskan tentang istilah dan definisi yang sering dipakai dalam kelistrikan yaitu dari arus, tegangan dan daya. Peserta diharapkan mampu memahami perbedaan istilah-istilah tersebut, menngenal satuan, serta penggunaannya.

Didalam sesi teori juga dijelaskan secara umum tentang sistim pembangkit, sistim transmisi dan sistim distribusi yang ada di Indonesia. Kemudian yang paling utama, peserta diharuskan menerangkan bahaya listrik, teknik pengamanan dari bahaya listrik serta pengetahuan tentang bagaimana cara menghitung kebutuhan daya listrik untuk rumah tangga dan industri rumah tangga skala kecil. Diakhir sesi teori dilakukan evaluasi pemahaman peserta tentang materi yang telah diberikan.

Sesi kedua adalah sesi praktek dimana peserta diberikan keterampilan untuk membaca gambar kerja, mengenal alat dan bahan yang digunakan untuk instalasi listrik. Kebutuhan untuk alat dan bahan bisa dilihat pada Tabel 1 dan Tabel 2. 
Tabel 1: Kebutuhan alat untuk pemasangan instalasi listrik

\begin{tabular}{llc}
\hline No & Alat & Jumlah \\
\hline 1 & Obeng Plus dan minus & 1 buah \\
2 & Tang potong & 1 buah \\
3 & Tang buaya & 1 buah \\
4 & Testpen & 1 buah \\
5 & Multimeter & 1 buah \\
6 & Gergaji pemotong pipa & 1 buah \\
7 & Palu & 1 buah
\end{tabular}

Tabel 2: Kebutuhan bahan untuk pemasangan instalasi listrik

\begin{tabular}{lll}
\hline No & Bahan & Jumlah \\
\hline 1 & MCB & 1 buah \\
2 & Saklar seri & 1 buah \\
3 & Saklar Tunggal & 1 buah \\
4 & Fitting & 3 buah \\
5 & Kotak Hubung & secukupnya \\
6 & Kabel NYA $2.5 \mathrm{~mm}$ & 15 meter \\
7 & Klem Pipa & secukupnya \\
8 & Stop Kontak & 1 buah \\
9 & Lampu & 3 buah \\
10 & Isolasi & I buah \\
\hline
\end{tabular}

\section{HASIL, PEMBAHASAN}

Tabel 3 merupakan peserta yang diutus untuk mengikuti pelatihan dari Nagari Gurun berdasarkan hasil pilihan dan kesedian peserta untuk mengikuti kegiatan pelatihan.

Tabel 3: Peserta yang mengikuti pelatihan

\begin{tabular}{lll}
\hline No & Kategori & Keterangan \\
\hline 1 & Jumlah peserta & 5 Orang \\
2 & Umur Peserta & 22-33 tahun \\
3 & Pekerjaan & Tidak ada pekerjaan tetap \\
4 & Pernah mempelajari tentang & 1 orang peserta pernah mempelajari instalasi \\
& instalasi listrik & listrik di SMK \\
5 & Jenis kelamin & 4 Laki-laki \\
& & 1 perempuan
\end{tabular}


6 Tingkat pendidikan

2 Orang lulusan diploma 3,

1 Orang lulusan SMK dan

2 orang lulusan SMP

Dari 5 peserta yang diutus hanya 5 orang yang mengikuti pelatihan. Peserta juga memiliki umur dengan range lebih kecil yaitu 22 sampai 33 tahun dan belum memiliki tetap. Dari 5 orang peserta hanya satu orang yang pernah mendapatkan pengetahuan instalasi listrik pada waktu di sekolah menengah. Kegiatan yang dilakukan pada sesi teori dan praktek bisa dilihat pada gambar 2 .

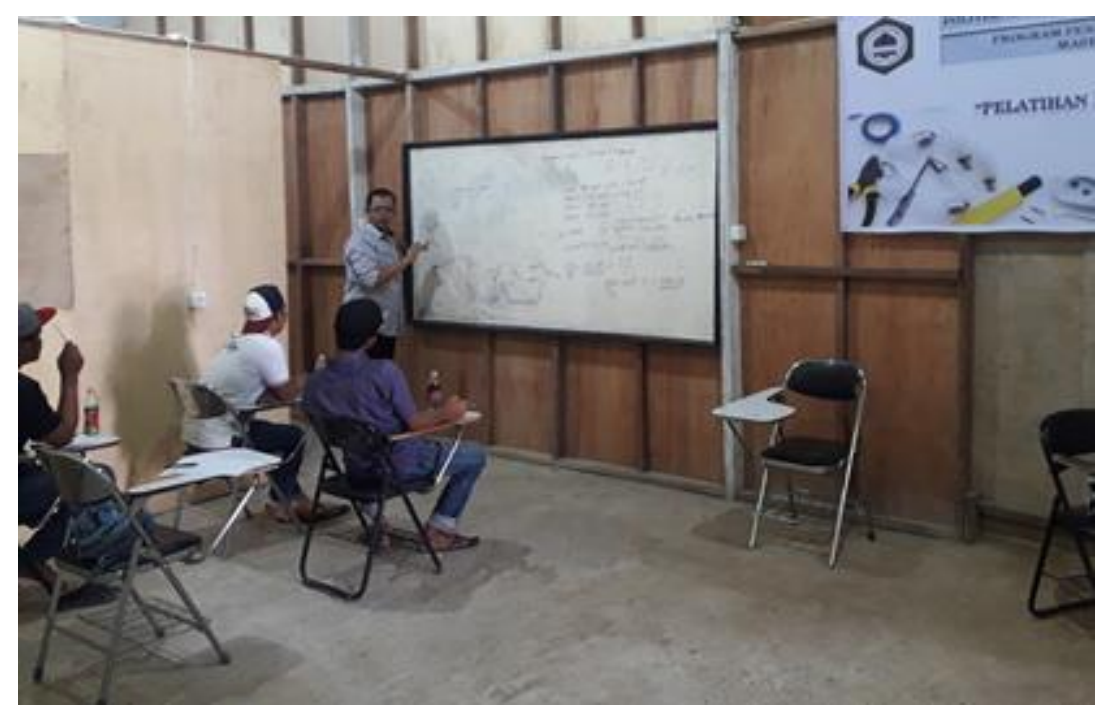

(a)

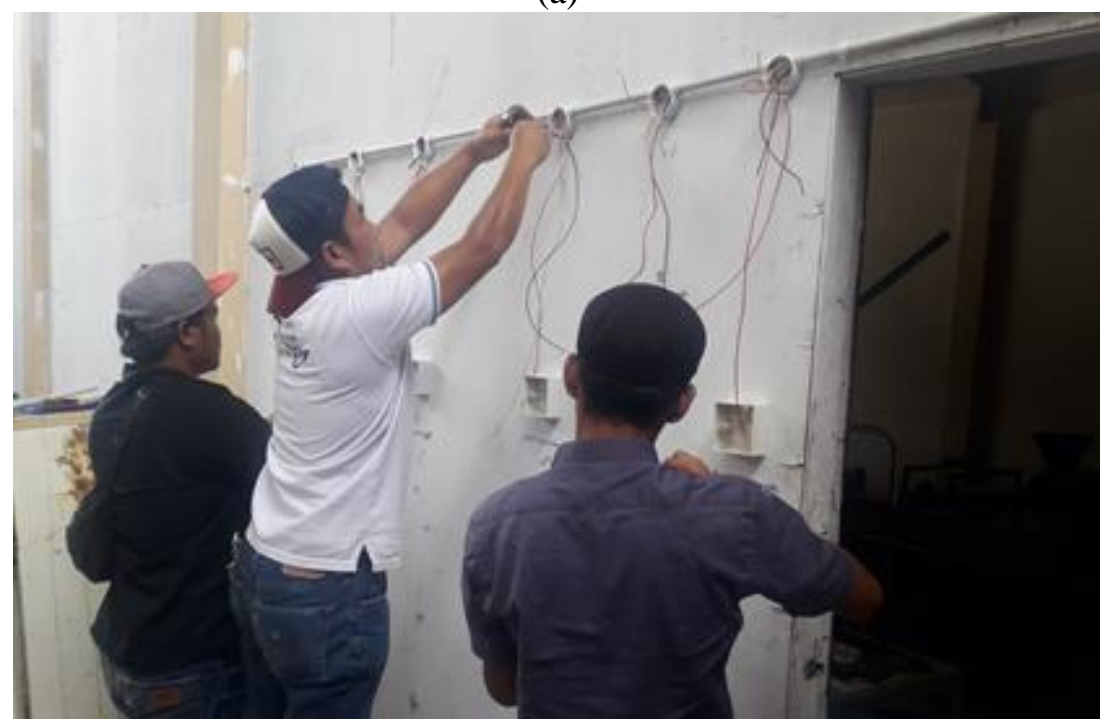

Gambar 2. (a) Sesi teori (b) Sesi Praktek

Adapun langkah pelaksanaan praktek dimulai dari menyiapkan alat dan bahan yang akan digunakan, penentuan tempat pemasangan komponen, instalasi PVC, kotak hubung sesuai dengan gambar selanjutnya, memasukan kabel kedalam pipa serta menyambung 
kabel kedalam $\mathrm{T}$ dos serta pada fitting, saklar dan stop kontak. Setelah dilakukan pemeriksaan maka langkah terakhir adalah menghubungkan dengan sumber daya.

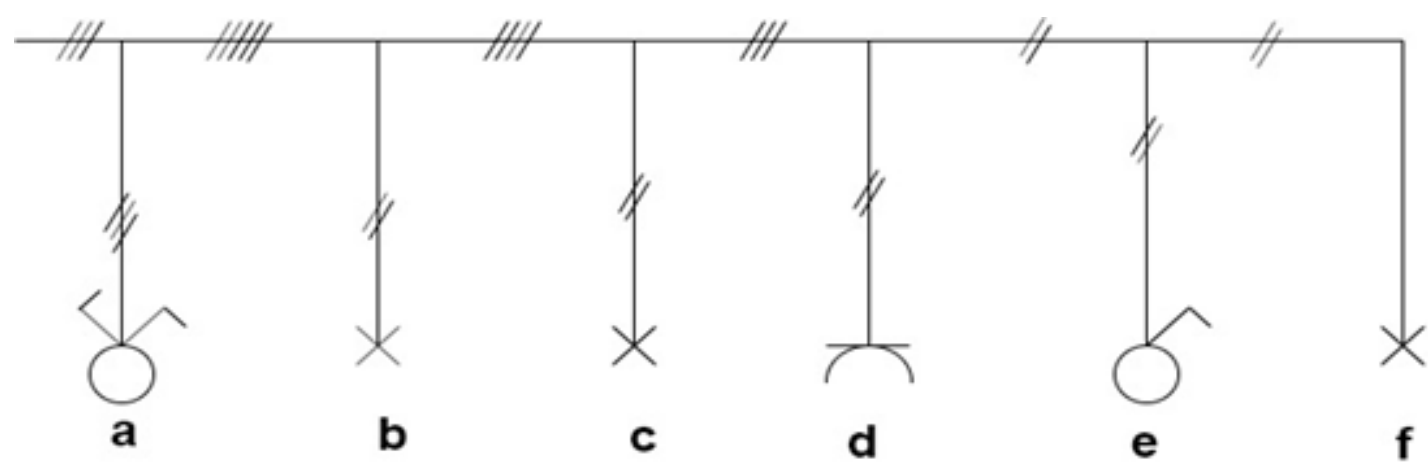

Gambar 3. Single-line diagram praktek instalasi listrik a.Saklar Seri, b.lampu 1 c.lampu 2, d.Stop Kontak, e. Saklar Tunggal dan f. Lampu 3.

Untuk melakukan pemasangan, peserta diharuskan mampu memahami gambar terlebih dahulu. Single-line diagram yang ditunjukkkan pada gambar 3(Yudistira \& Putera, 2017) merupakan instalasi listrik rumah tangga sederhana dengan pemasangan untuk 3 buah lampu dan satu buah stop kontak. Garis-garis sejajar menandakan jumlah kabel yang harus disertakan kedalam pipa PVC. Saklar berfungsi untuk memutuskan arus yang masuk dari fasa dan hanya stop kontak yang memiliki kabel pentanahan (Syahbeni et al. 2018)

\section{SIMPULAN}

Seluruh peserta pelatihan telah mengetahui prinsip instalasi listrik, menghitung kebutuhan daya listrik serta mampu melakukan instalasi listrik untuk rumah tangga mulai dari MCB hingga instalasi daya serta instalasi penerangan. Untuk melakukan pemasangan, peserta diharuskan mampu memahami gambar terlebih dahulu dan sebagai pemula sebaiknya perlu pendampingan. Pelatihan selanjutnya perlu mengundang atau berkerja sama dengan biro PLN, sehingga peserta dapat terjun langsung dan dapat menambah tenaga teknis bagi biro sediri.

\section{UCAPAN TERIMAKASIH}

Ucapan terimakasih disampaikan kepada Politeknik Pertanian Negeri Payakumbuh yang telah membiayai kegiatan ini melalui dana DIPA tahun anggaran 2019

\section{DAFTAR PUSTAKA}

Adisti Sukmaningrum, A. I. (2017). Memanfaatkan Usia Produktif Dengan Usaha Kreatif Industri Pembuatan Kaos Pada Remaja Di Gresik. Paradigma, 5(3), 1-6. 
Kementerian Riset, T. dan P. Statuta Politeknik Pertanian Negeri Payakumbuh, Pub. L. No. 38 (2017). Indonesia.

Statistik, B. P. (2017). Banyaknya Penduduk Berumur 15 Tahun ke atas Menurut Jenis Kegiatan dan Jenis Kelamin. Retrieved from https://limapuluhkotakab.bps.go.id/statictable/2015/05/14/12/banyaknya-pendudukberumur-15-tahun-ke-atas-menurut-jenis-kegiatan-dan-menurut-jenis-kegiatan-danjenis-kelamin.html

Syahbeni. M, Budiman. A, Syelly. R, Laksmana. I, Hendra. (2018). Rancang Bangun Pendeteksi Curah Hujan Menggunakan Tipping Bucket Rain Sensor dan Arduino Uno. Agroteknika 1(2), 51-62

Yudistira, \& Putera, P. (2017). BKPM Instalasi Listrik. Politeknik Pertanian Negeri Payakumbuh. 